\title{
Anaplastic Astrocytoma, Not Otherwise Specified
}

National Cancer Institute

\section{Source}

National Cancer Institute. Anaplastic Astrocytoma, Not Otherwise Specified. NCI

Thesaurus. Code C129292.

Anaplastic astrocytoma in which there is insufficient information on the IDH genes status. 